Pacific Northwest National Laboratory

Operated by Battelle for the U.S. Department of Energy

\section{Past, Present, Future Erosion at Locke Island}

Hanford Cultural Resources Project

B. N. Bjornstad

June 2006

Prepared for the U.S. Department of Energy under Contract DE-AC05-76RL01830 


\title{
DISCLAIMER
}

This report was prepared as an account of work sponsored by an agency of the United States Government. Neither the United States Government nor any agency thereof, nor Battelle Memorial Institute, nor any of their employees, makes any warranty, express or implied, or assumes any legal liability or responsibility for the accuracy, completeness, or usefulness of any information, apparatus, product, or process disclosed, or represents that its use would not infringe privately owned rights. Reference herein to any specific commercial product, process, or service by trade name, trademark, manufacturer, or otherwise does not necessarily constitute or imply its endorsement, recommendation, or favoring by the United States Government or any agency thereof, or Battelle Memorial Institute. The views and opinions of authors expressed herein do not necessarily state or reflect those of the United States Government or any agency thereof.

\author{
PACIFIC NORTHWEST NATIONAL LABORATORY \\ operated by \\ BATTELLE \\ for the \\ UNITED STATES DEPARTMENT OF ENERGY \\ under Contract DE-AC05-76RL01830
}

Printed in the United States of America
Available to DOE and DOE contractors from the Office of Scientific and Technical Information,
P.O. Box 62, Oak Ridge, TN 37831-0062;
ph: (865) 576-8401
fax: (865) 576-5728
email: reports@adonis.osti.gov

\author{
Available to the public from the National Technical Information Service, \\ U.S. Department of Commerce, 5285 Port Royal Rd., Springfield, VA 22161 \\ ph: (800) 553-6847 \\ fax: (703) 605-6900 \\ email: orders@ntis.fedworld.gov \\ online ordering: http://www.ntis.gov/ordering.htm
}

This document was printed on recycled paper. 


\section{Past, Present, Future Erosion at Locke Island}

\section{Hanford Cultural Resources Project}

B. N. Bjornstad

June 2006

Prepared for

the U.S. Department of Energy

under Contract DE-AC05-76RL01830

Pacific Northwest National Laboratory

Richland, Washington 99352 


\section{Summary}

Significant erosion has occurred along the northeast side of Locke Island over the last 10 to 20 years. This has removed substantial volumes of sediment from the island, which includes cultural materials, and redistributed the material downstream, interfering with some of the best and last salmon spawning habitat along the Columbia River (Mueller and Geist 1999). The principal cause of erosion is the massive Locke Island Landslide complex opposite the river along the White Bluffs, which constricts the flow of the Columbia River and deflects the river's thalweg southward against the island. Movement of the landslide, which initiated in the early 1970s as a result of irrigation water applied behind the White Bluffs, now appears to move primarily as a result of high stream flows of the river. Combined with landslide movements, accelerated calving along the northeast bank of Locke Island also appears to be related to high stream-flow events of the river. Rapid rises and falls of the river from outflow of Priest Rapids Dam, especially during periods of high stream flow, make the riverbanks much more unstable and prone to slumping.

Monitoring erosion at Locke Island has been ongoing since 1994. Since January 1996, a network of survey stakes has been in place to monitor riverbank recession; up to 40 meters of erosion has occurred during this time. The most significant erosion occurred during an exceptionally high runoff (400,000 cubic feet per second [cfs]) event in mid-June 1997. During this period alone, up to 10 meters of riverbank erosion occurred. The most intense erosion occurs where the river channel is narrowest, which is naturally coincident with the highest flow rate. Up to several meters of erosion also occurred during elevated stream flows (200,000 to 300,000 cfs) in February and June of 1996, and again in midJune of 2002. In between these events, when stream flows have been below 200,000 cfs, little or no erosion of Locke Island has occurred.

It appears the present hiatus in landslide movement and erosion of Locke Island may only be temporary. Based on historical stream-flow data of the Columbia and Yakima Rivers over the last 100 years, there is a high likelihood that erosion of Locke Island will recur in the future, especially during periods of high stream flow, when the Locke Island Landslide can be expected to advance and high river levels lead to saturation and undercutting of riverbanks. Some erosion of the island could also occur every few years during stream flows between 200,000 to 300,000 cfs. Severe erosion, like that of 1996-1997, can be expected from stream flows $\geq 400,000$ cfs, which recur about every 20 to 30 years.

Only the middle portion on the northeast side of Locke Island is threatened by significant erosion. Little or no erosion has occurred on other parts of the island and that is expected to continue. Sediment bars are presently forming along the southeast side of the island; these bars are composed of the sediment eroded from the northeast bank of the island and from the toe of the landslide upstream. 


\section{Contents}

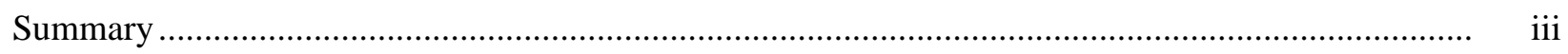

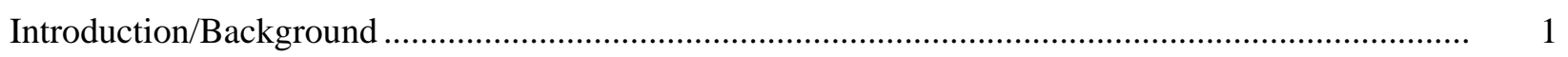

History of Landsliding and Erosion ........................................................................................ 5

High Stream Flows of the Columbia River............................................................................. 9

Monitoring of Movement Along Locke Island Landslide ................................................................ 13

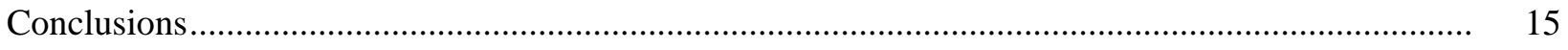

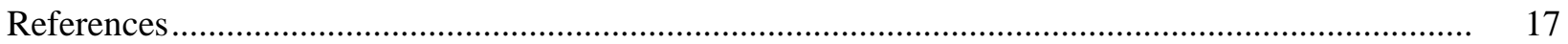

\section{Figures}

1 Map Showing Sources of Water That Initiated Modern Landslide Movements Along the White Bluffs

2 Aerial View of Locke Island Taken September 2001 Showing Extent of Riverbank Erosion

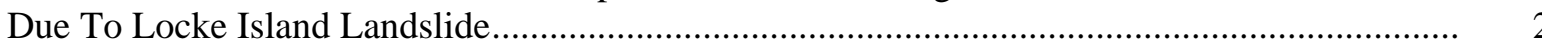

3 Most Recent Aerial Photograph, Taken in 2002, of Locke Island and the Locke Island Landslide Complex ................................................................................................................ 3

$4 \quad$ First Aerial Image of Locke Island Collected in 1941.......................................................... 5

5 Measuring Amount of Riverbank Recession Within a Network of Surveyed Monitoring

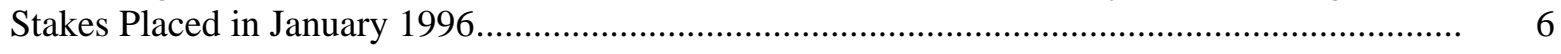

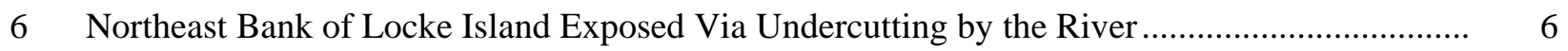

7 Cumulative Erosion at 21 Monitoring Stations on Locke Island Since January 1996 .................. 7

8 Plot Showing Correlation Between Columbia River Stream Flow and Erosion Measured

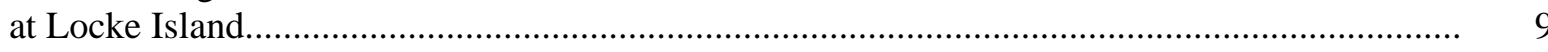

9 Peak Flows of the Columbia River Below Priest Rapids Dam Since the Beginning of

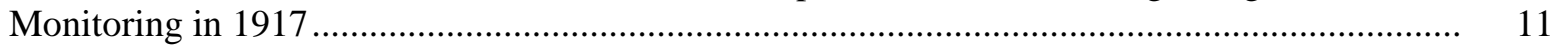

10 Peak Stream Flow of the Walla Walla River Since 1952 ....................................................... 11

11 Peak Stream Flow of the Yakima River at Kiona Since 1905.................................................. 12 


\section{Introduction/Background}

Recent landsliding along the White Bluffs began in the early 1970s as a result of irrigation water delivered to unlined wastewater ponds and canals behind the bluffs to enhance the wildlife in this area (Hays and Schuster 1987; Schuster et al. 1987; Nickens et al. 1998; Triangle Associates 2003); diversion of this irrigation water began in the 1960s. The percolating irrigation water moves downward through relatively permeable sands of the Hanford formation (Ice-Age flood deposits) until it reaches the finegrained, fluvial-lacustrine Ringold Formation. The percolating water perches on top of the tight Ringold clays and silts and moves laterally along a paleoflood channel eroded into the Ringold Formation ("B" in Figure 1). Landslides occur where excess perched water seeps out from the paleochannel along the bluff

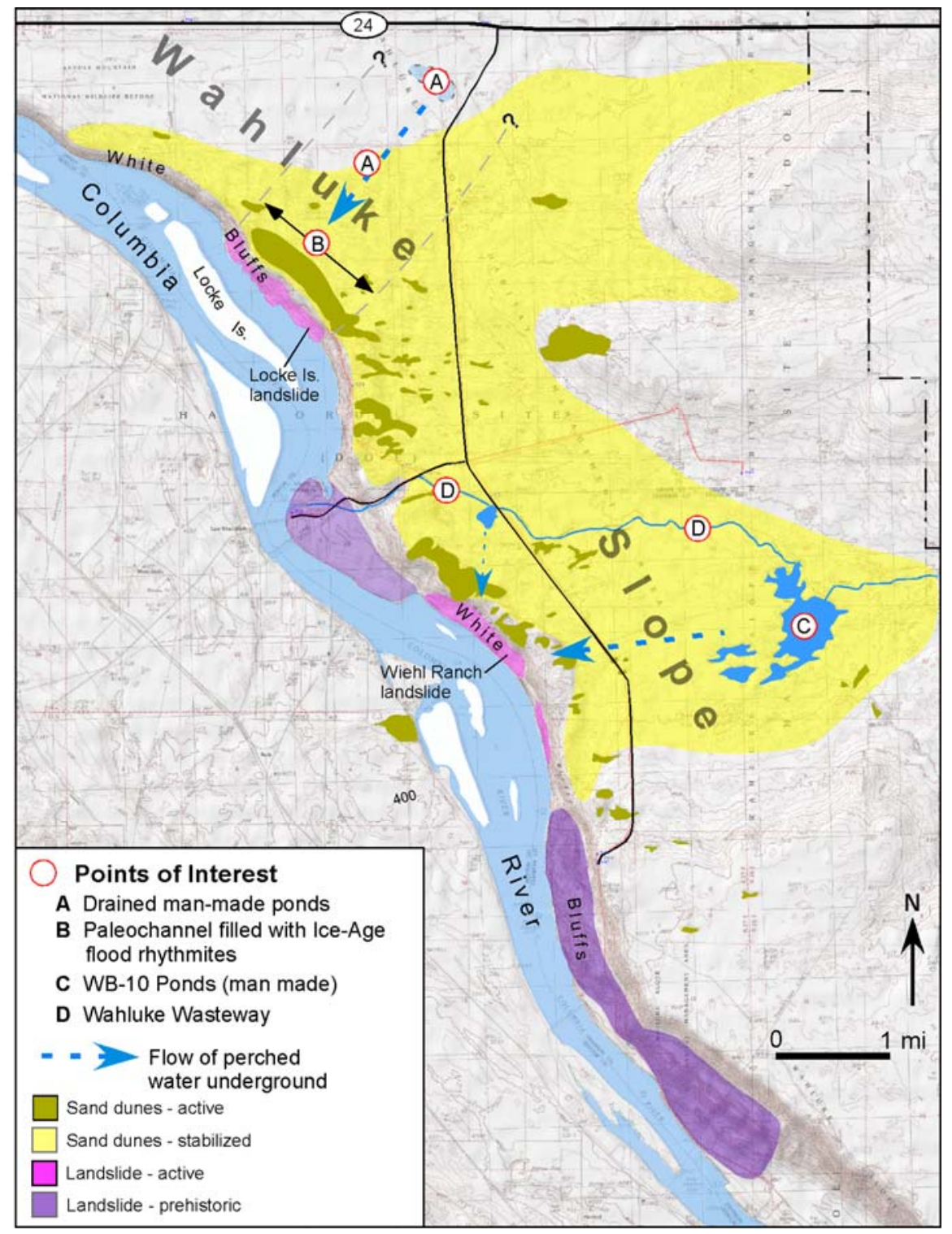

Figure 1. Map Showing Sources of Water That Initiated Modern Landslide Movements Along the White Bluffs (Bjornstad 2006) 
face. Because underground seepage naturally flows along the base of the paleochannel, it is not a coincidence that the $\sim 1$-mile width of the active landslide is exactly the same width as the paleochannel (Figure 1). Here, where the ground is saturated, the wet, soft sediments of the Ringold Formation lose much of their internal strength, leading the bluffs to slump. Slumping began in the late 1970s and continues today, even though the ponds ("A" in Figure 1) were completely drained in the mid-1990s in an attempt to stop the sliding. The rate of movement at the toe of the landslide has gradually slowed from as much as $20 \mathrm{ft} / \mathrm{yr}$ in 1998 to the point where there has been little or no detectable movement in recent years.

Movement of the landslide has narrowed the river channel and shifted it southwestward. Furthermore, the river is forced to flow more rapidly around the outside of the curve in the river created by the landslide. This has focused the river's energy to the northeast bank of Locke Island, causing considerable undercutting and erosion (Figures 2 and 3). Sediments calving away from the steep riverbank consist of mostly fine-grained, Holocene-age, overbank alluvial deposits of the Columbia River (Bjornstad and Cadoret 1997). These deposits contain ancient cultural artifacts and remains (Nickens et al. 1998).

In 1998, the Army Corps of Engineers (USCOE 1998) produced a document discussing feasibility of various alternatives to control erosion along Locke Island and the landslide. To date no action has been taken to mitigate erosion, except to cut off the flow of water to some of the ponds responsible for initiating the landslides.

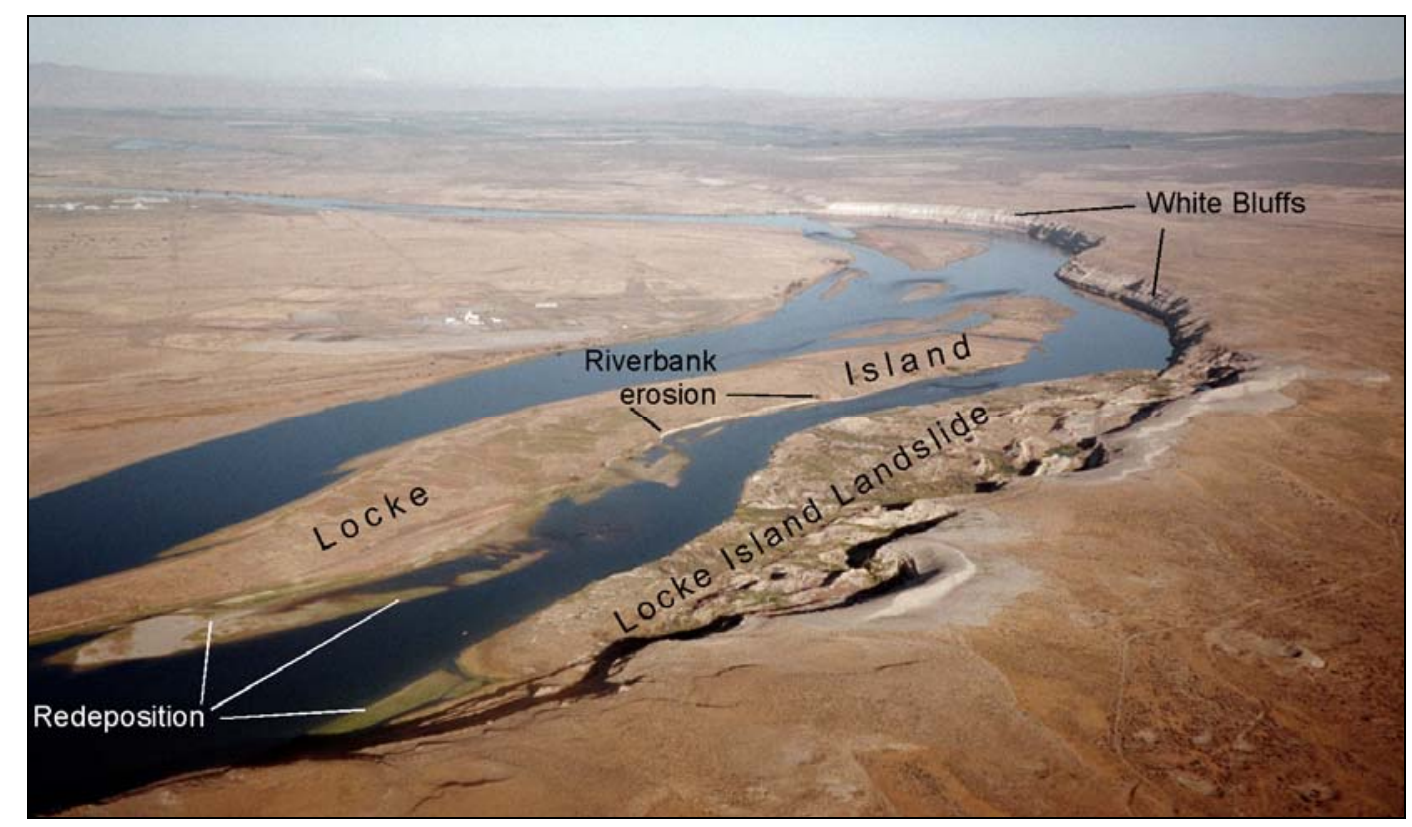

Figure 2. Aerial View of Locke Island (looking West) Taken September 2001 Showing Extent of Riverbank Erosion Due To Locke Island Landslide (The most extensive erosion of the island occurs where the steep, fresh, riverbank face is exposed. Eroded sediment from the island as well as the landslide is being redeposited just downstream from where the river widens, current slows, and sediment settles out of suspension. Bob Peterson photo.) 


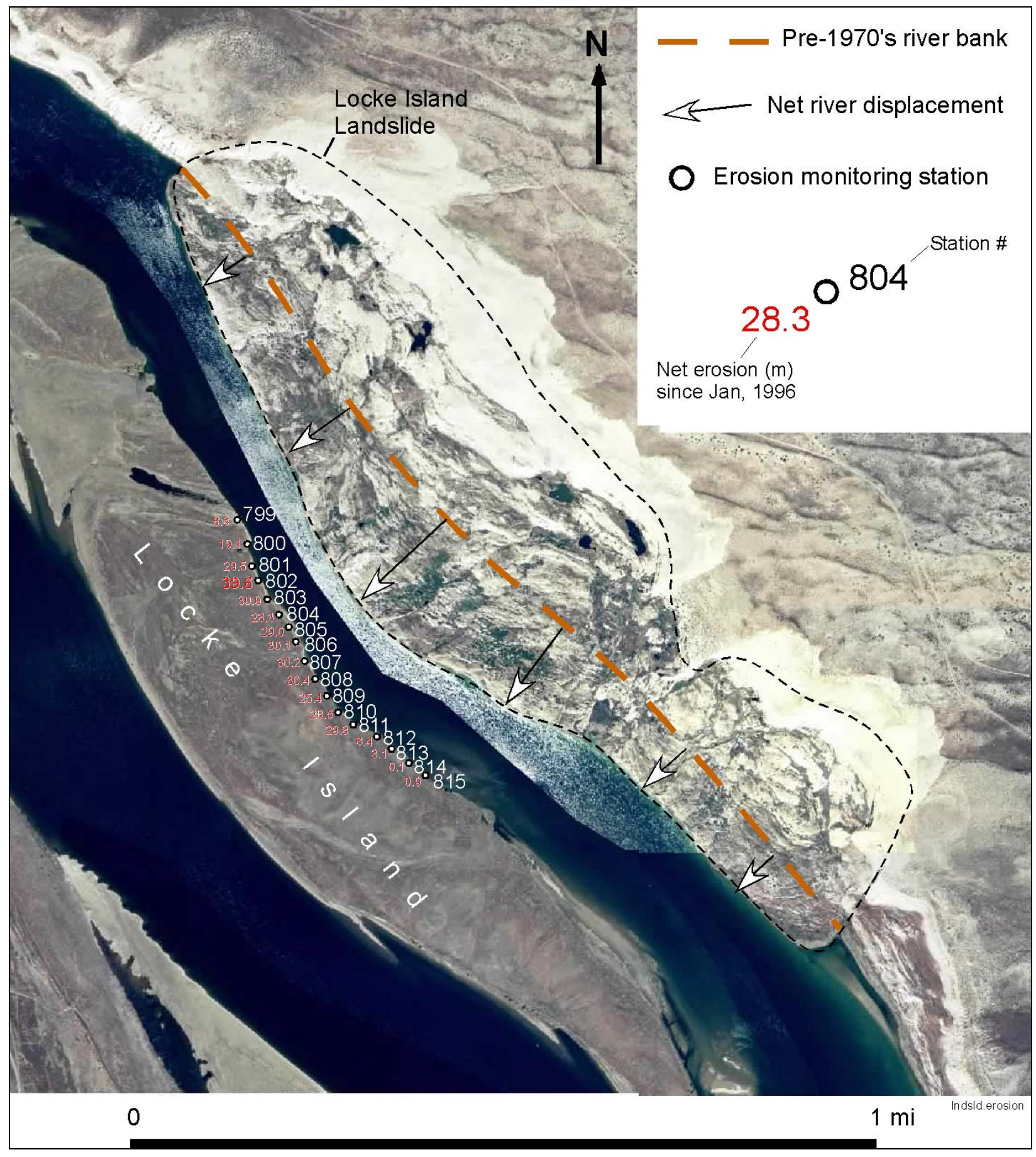

Figure 3. Most Recent Aerial Photograph, Taken in 2002, of Locke Island and the Locke Island Landslide Complex (Erosion monitoring transects are indicated in white and total erosion since 1996 is indicated in red. The Columbia River flows from upper left to lower right.) 


\section{History of Landsliding and Erosion}

A sequence of aerial photographs shows the initiation and growth of the Locke Island Landslide over the years since the first image was collected in 1941 (Figure 4). The entire series of images is presented in Nickens et al. (1998) and USBR (1999). In the photographs, the bluffs begin to slump in the mid-1970s and continue with accelerated growth of the landslide into 1982 when the last image was collected. Since these reports came out, a more recent aerial survey was performed (Figure 3). Historical aerial photos show slumping that starts across from the southeast end of Locke Island that worked its way northwestward. Most of the recent landsliding has occurred to the northwest, directly across from the middle portion of Locke Island (Figure 3). In 2002, it appears the landslide is still very well established and strongly influences flow of the river in the vicinity of Locke Island (Figure 3).

Alarmed by the high rate of erosion taking place on Locke Island, PNNL scientists installed a series of transects in 1996 along the northeast side to identify the location and rates of erosion (Figure 5). The transects were placed directly across from the landslide in the area where fresh faces of the island were being exposed as slump blocks calved into the river (Figure 6).

Not coincidentally, the most erosion of Locke Island has occurred along the outside of a bend in the river, and where the river channel is narrowest where it is forced around the advancing lobe of the slide

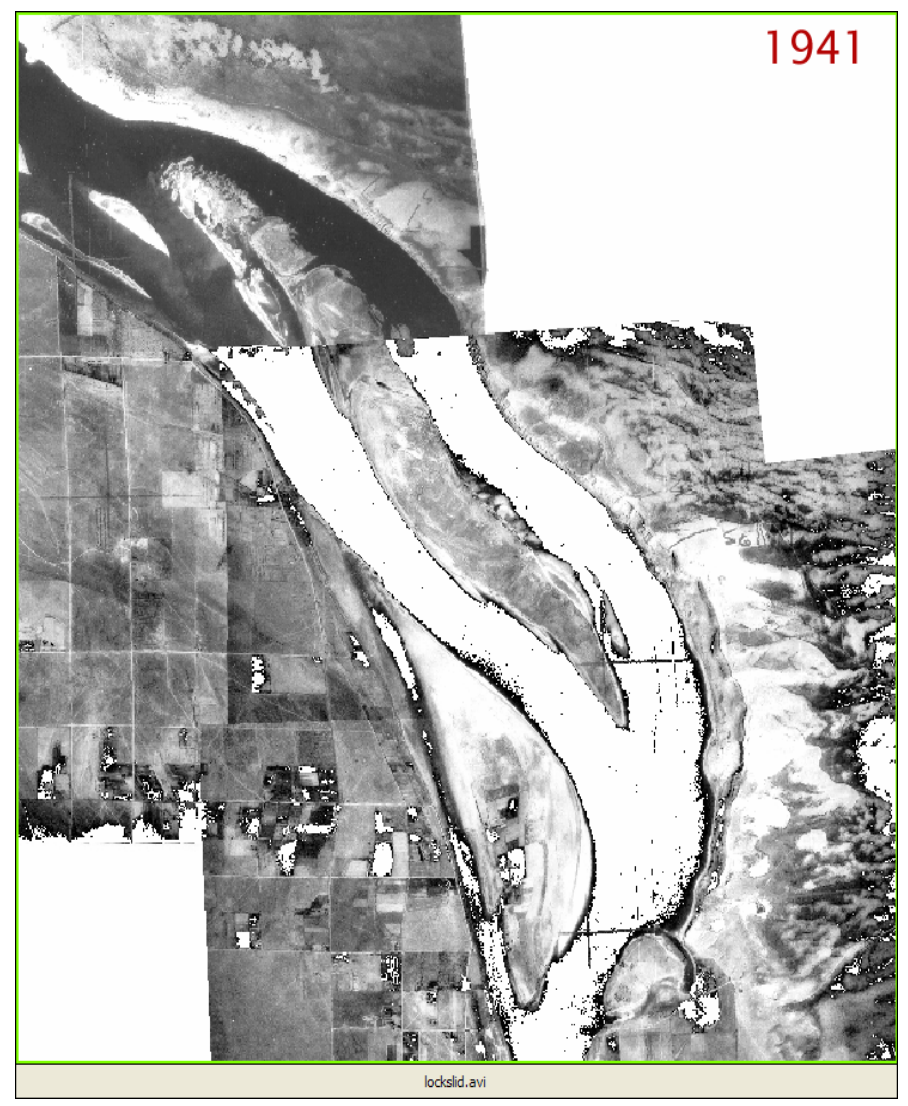

Figure 4. First Aerial Image of Locke Island Collected in 1941 (Notice there is little evidence of sliding, and in this image, the bluffs as well as Locke Island are completely intact.) 


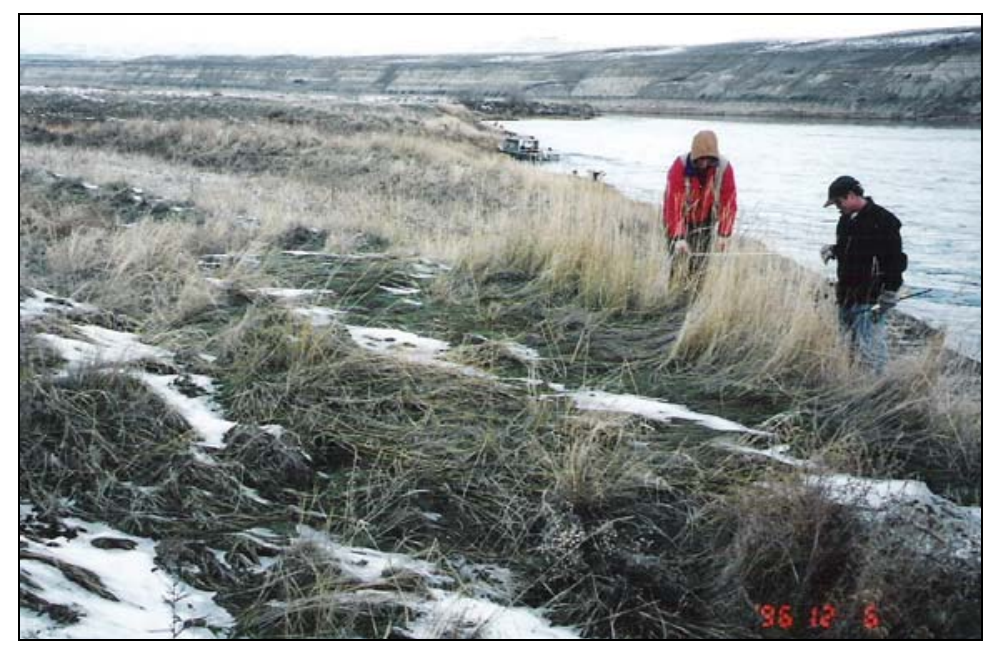

Figure 5. Measuring Amount of Riverbank Recession Within a Network of Surveyed Monitoring Stakes Placed in January 1996
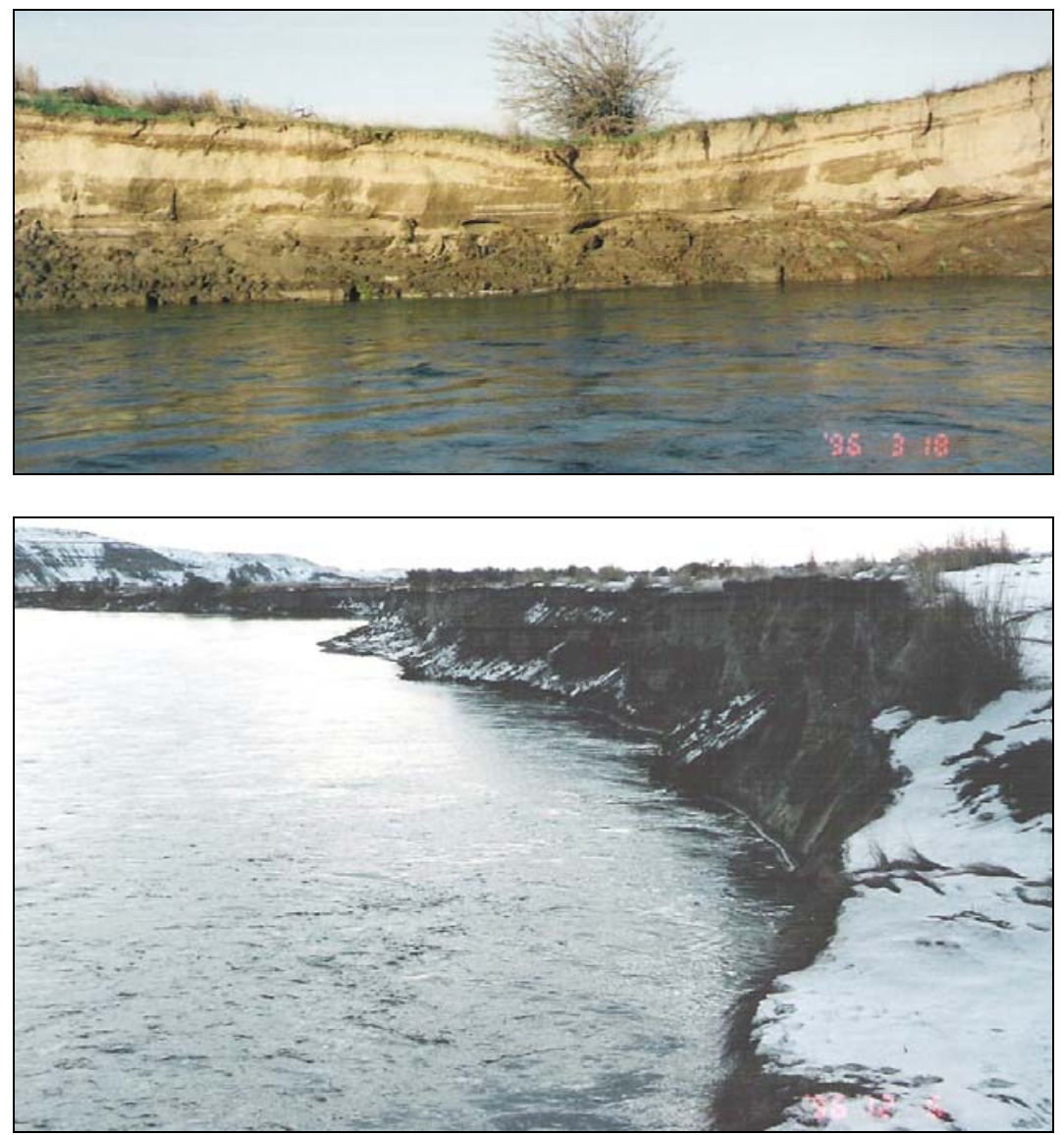

Figure 6. Northeast Bank of Locke Island Exposed Via Undercutting by the River (Upper photograph, taken in mid-March 1996, shows slumped debris at base of steep cut bank that is transported away during high water (lower photo), which saturates and loads the stream bank. During a sudden, rapid drop in river level, more slumping is likely to occur.) 
(Figure 3). Note that the maximum amount of erosion (almost $40 \mathrm{~m}$ at Station \#802) has occurred just upstream of the narrowest part of the channel. Just upstream, in Figure 6 (top), is the freshly exposed riverbank, exposed by active slumping. Because of the venturi effect, the speed of the water here is greatest and capable of doing the most erosive work. The higher velocity of the river here is not only more effective at undercutting the northeast bank of the island but also at transporting away the slumped material, which leads to more slumping (Figure 6).

The timing and amount of erosion that has occurred at transects since January 1996 is shown graphically in Figure 7. This chart shows very rapid, intermittent recession of the northeast bank of Locke Island from the inception of monitoring (early 1996) through mid-summer of 1997. Since that time erosion has proceeded at a slow average rate. An exception is up to a few meters of erosion that occurred briefly in mid-June of 2002.

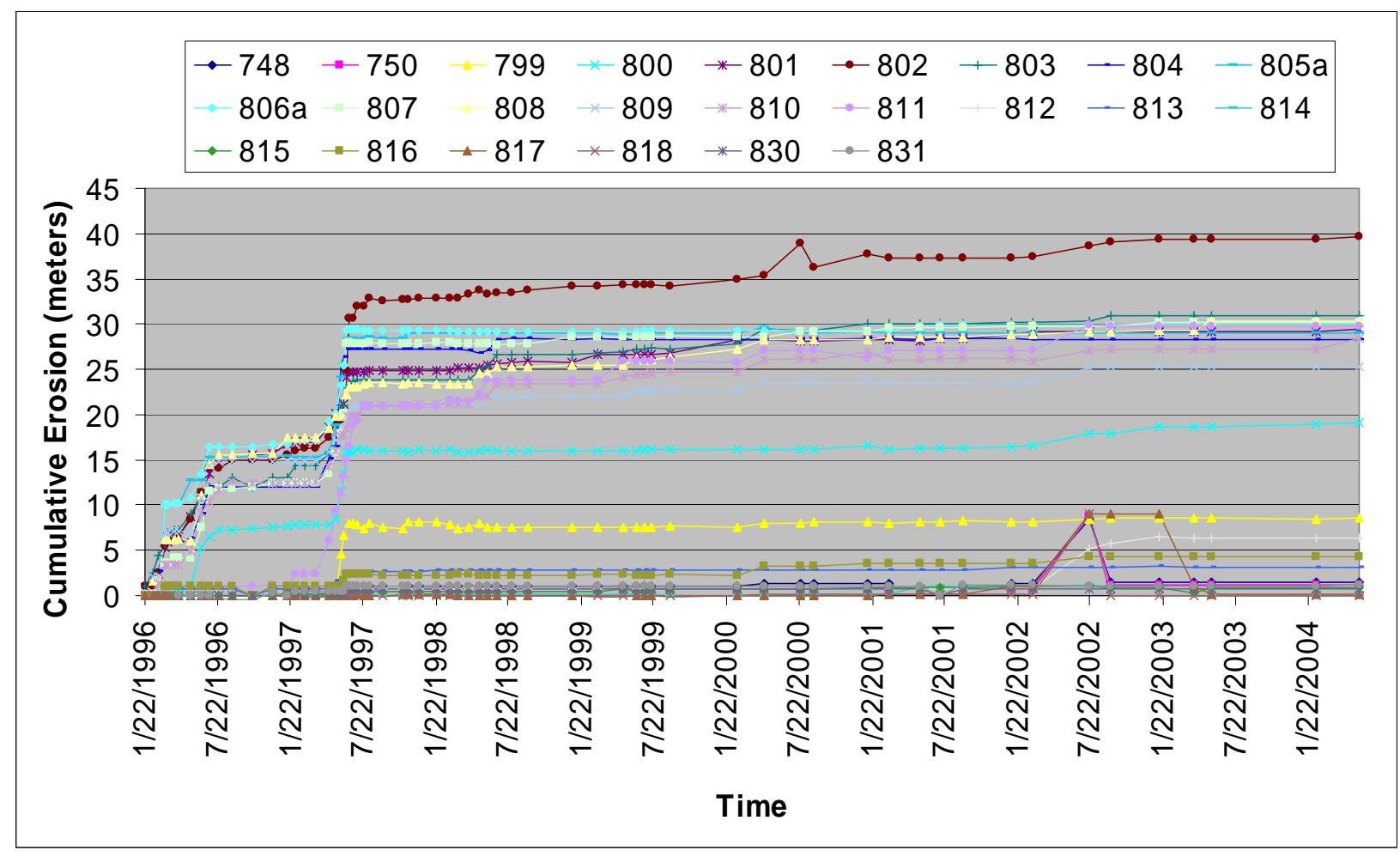

Figure 7. Cumulative Erosion at 21 Monitoring Stations on Locke Island Since January 1996 


\section{High Stream Flows of the Columbia River}

Erosion of Locke Island appears to be directly related to rapid fluctuations and elevated stream flows of the Columbia River. Therefore, it is useful to understand the causes and timing of changes in stream flow, both natural and manmade. Unlike a natural river, the flow of the Columbia River is strongly influenced, both diurnally and seasonally, by the multitude of dams along its length. Historically, the highest stream flows of the Columbia River occur in mid-June associated with spring runoff. While high precipitation or rapid snow melt events may occur at other times of the year, these may be dampened from the record for the Columbia River because of temporary storage behind hydroelectric dams (mostly Grand Coulee). A good example of this is the February 1996 incident where a deep snowpack that covered the Pacific Northwest suddenly melted during a rapid warming event. Most of the naturally flowing rivers (e.g., Yakima River) of the region flooded, yet this event did not produce a discharge in the Columbia River much greater than a number of annual spring runoff events below Priest Rapids Dam since that time (Figure 8). Despite being dampened, the February 1996 flood event still generated some significant erosion along the banks of Locke Island, however.

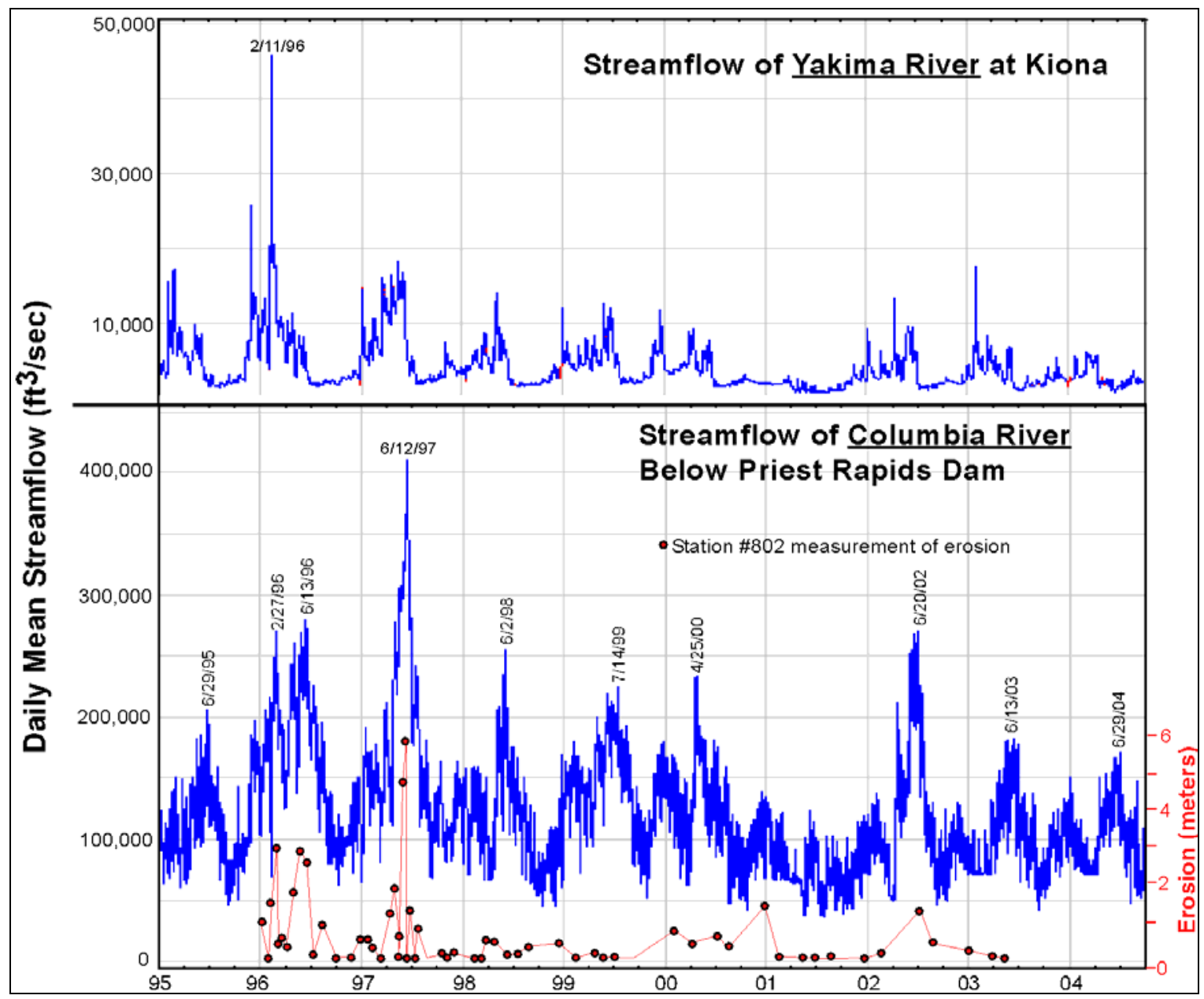

Figure 8. Plot Showing Correlation Between Columbia River Stream Flow and Erosion Measured at Locke Island (Natural flow of Yakima River shown at top.) 
In Figure 8, the average daily stream flow of the Columbia River is plotted since 1995, just prior to installation of erosion-monitoring transects. The erosion observed at Station \#802 (greatest amount of erosion measured) is plotted beneath stream flow. Figure 8 clearly shows a direct correlation between the amount of erosion and stream flow of the Columbia River below Priest Rapids Dam. Most of the highest stream flows from the Columbia River come in mid-to-late June during spring runoff and as Grand Coulee Dam releases the greatest amount of water from the upper Columbia River stored over the winter and spring.

Since stream flow of the Columbia River at Locke Island is moderated by the amount of water released from dams upstream, measured stream flows may not be a true reflection of natural climatic conditions. Wanapum and Priest Rapids Dams work in concert to regulate the flow of the Columbia River and prevent flooding of the Tri-Cities like that which occurred in June 1894 (700,000 cfs at International Boundary). The dams are generally run-of-the-river dams, meaning they don't hold back significant quantities of water (like Grand Coulee Dam) and about as much water is released from them as comes in. Because operators of the dams must try to accommodate and balance many uses of the river (e.g., salmon runs, irrigation, recreation), daily flows can fluctuate significantly. So, for the purposes of comparison, a plot of the nearby Yakima River, whose flow is uncontrolled and purely representative of natural conditions, is also plotted, over the same period of time, in Figure 8. While much more noise is apparent in the plot of the Columbia River due to frequent diurnal changes in outflow from Priest Rapids Dam, the same general highs and lows exist for each plot. Therefore, despite being controlled by man, stream flows below Priest Rapids Dam overall appear to be a reflection of the natural flow after the diurnal "noise" is removed. However, as discussed above, some significant runoff-producing events may be dampened via storage behind Grand Coulee Dam.

Also from Figure 8, it appears that little or no erosion has occurred along Locke Island as long as stream flows are $<200,000$ cfs. The most erosion occurred in mid-June 1997 during a 20 -year flood when the river flowed at 400,000 cfs. At other times (e.g., 2/96, 6/96, 6/02) some erosion still occurred at 300,000 cfs. Historically, the Columbia River below Priest Rapids Dam has had flows $\geq 400,000$ cfs only once (6/97) in the last 30 years. Prior to the early 1970s, stream flow of the Columbia River below Priest Rapids Dam exceeded 400,000 cfs on a regular basis, exceeding 400,000 cfs at least a couple of dozen times since record-keeping began in 1917 (Figure 9). However, regulation of flow behind the dams since the 1970s appears to have kept flows under 400,000 cfs, except in rare instances like the June 1997 flood of the Columbia River. But even with this flow regulation, flows approaching 300,000 cfs, still powerful enough to produce erosion at Locke Island (see Figure 8), have occurred several times since the 1970s.

To determine the frequency of the major flooding events, like that which eroded Locke Island during 1996-1997, it is instructive to look at the flow of other rivers, unregulated by dams. For this exercise, two of the nearest rivers to the Columbia are examined: the Yakima and Walla Walla Rivers. Prior to the flooding of the Walla Walla River in 1997, the next earliest flood occurred 32 years earlier in 1965 (Figure 10). Yakima River peak flows, comparable to those of 1997, have occurred five times since 1906, a recurrence interval of 20 years (Figure 11). 


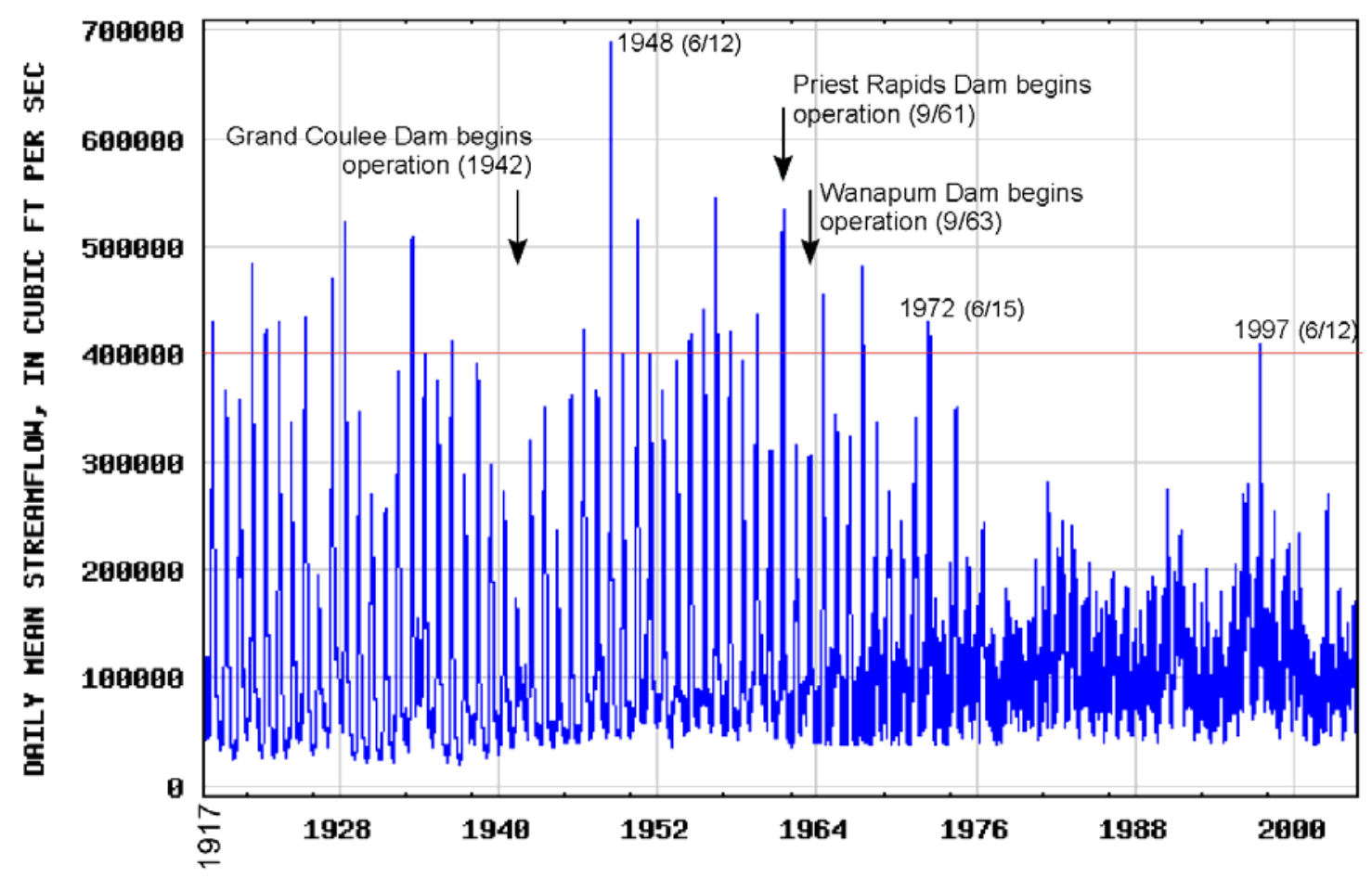

Figure 9. Peak Flows of the Columbia River Below Priest Rapids Dam Since the Beginning of Monitoring in 1917

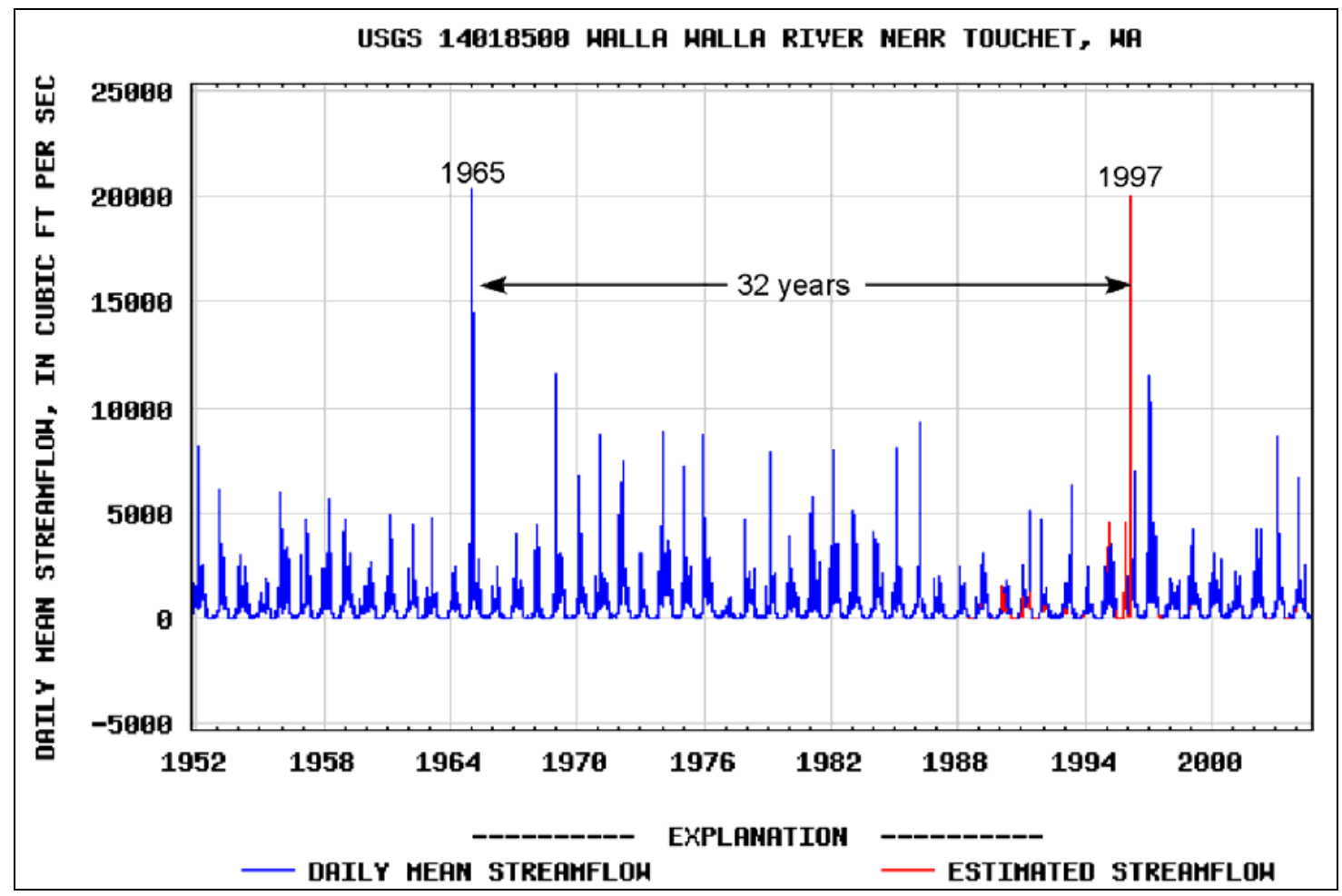

Figure 10. Peak Stream Flow of the Walla Walla River Since 1952 (Recurrence interval of 1996-1997 flood magnitude $\sim 32$ years.) 


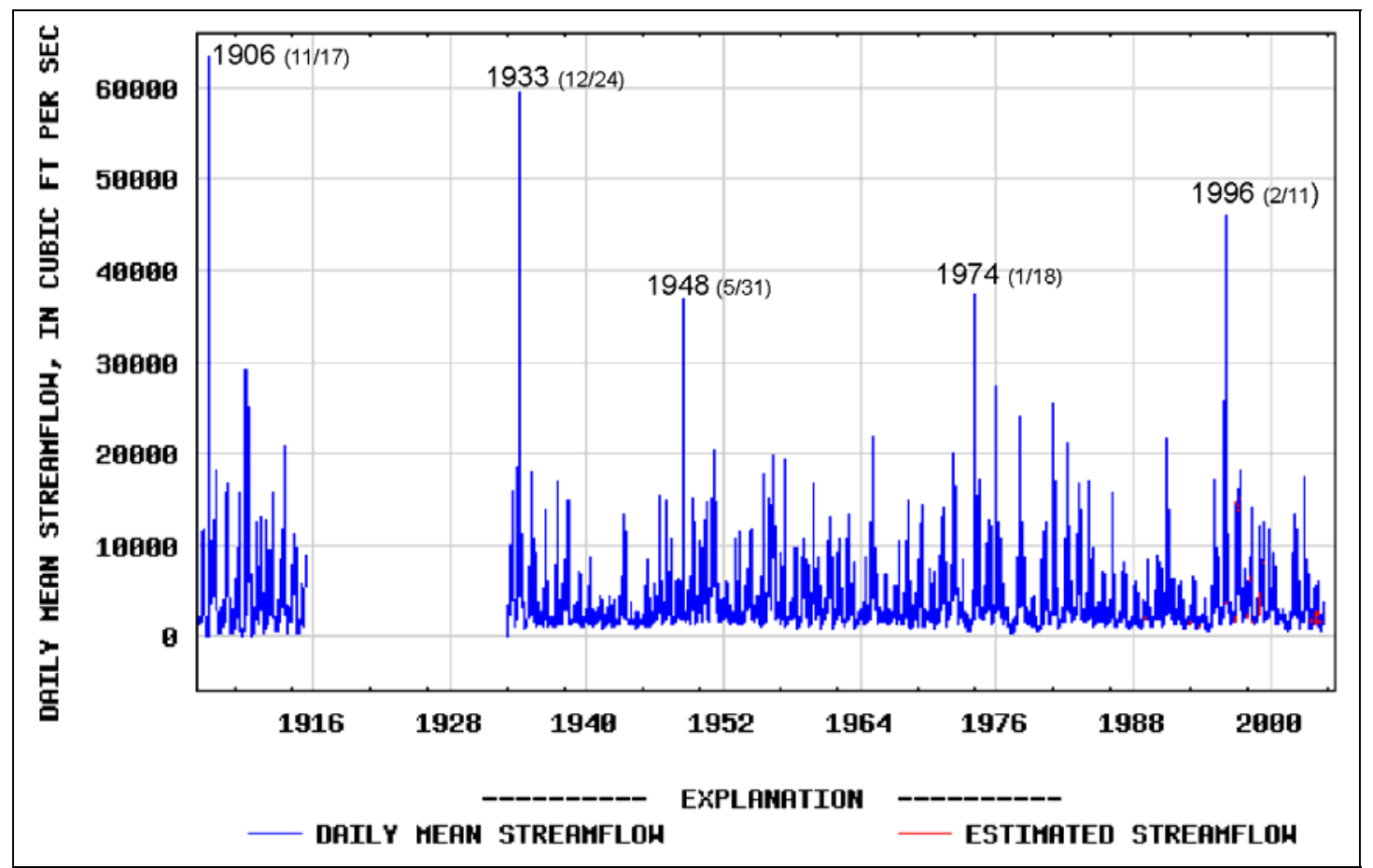

Figure 11. Peak Stream Flow of the Yakima River at Kiona Since 1905 (Recurrence interval of 1996-1997 flood magnitude $\sim 20$ years.) 


\section{Monitoring of Movement Along Locke Island Landslide}

In 1998, the U.S. Bureau of Reclamation drilled eight boreholes behind the White Bluffs and two boreholes on the landslide itself to characterize and monitor the Locke Island Landslide. ${ }^{1}$ Soon after drilling, the two boreholes on the slide were sheared off at depth, apparently due to movement along the shear plane at the base of the slide. In addition to drilling of boreholes, in 1997, six survey pins were placed at the toe of the landslide to monitor movements at the surface.

Up to 20 feet of movement occurred at the toe of the landslide during the first year of monitoring (1997-1998). The movement gradually slowed over the next few years and almost no movement was recorded over the last few years. Most recent movement of the slide appears to be related to high water levels during large stream flow events, which may erode, load, and lubricate the toe of the landslide, causing it to accelerate forward. ${ }^{1}$ Even though relatively little movement of the landslide has happened recently, this may be only temporary because of the relatively low snow packs and stream flows of the last few years. During the next period of high stream flow (300,000-400,000 cfs), which can be expected every few years, the landslide will likely surge forward. In turn, continued movement of the landslide will keep the river pushed up against Locke Island, which could lead to continued undercutting and erosion.

\footnotetext{
${ }^{1}$ Personal communication, Dan Hubbs, U.S. Bureau of Reclamation, September 2005.
} 


\section{Conclusions}

More erosion can be expected along the northeast side of Locke Island that faces the landslide, as long as the landslide stays active and keeps the river pushed up against Locke Island. When, and if, the landslide stops moving the river will widen its channel, currents will slow down, and erosion should subside or end. However, this does not seem likely given the history of high stream flows for the river. Even though landsliding and erosion appear to have stopped, this is likely only temporary and erosion and landslide activity will likely be renewed during high stream flows in the foreseeable future.

The last period of major erosion at Locke Island occurred with a seasonal flood ( 400,000 cfs) in June 1997. Based on the historical stream flow measurements for the Columbia, Yakima, and Walla Walla Rivers, the recurrence interval for floods of similar magnitude is about once every 20 to 30 years. However, some erosion may still occur from stream flows 200,000 to 300,00 cfs, which occur every few years. Thus, we can expect erosion of Locke Island, similar to 1996-1997, about once every 20 to 30 years. Some erosion may also be expected every few years from smaller flows. Erosion could be especially severe if landslide movements keep the river channel narrow and pushed up against the island.

Because of the venturi effect, maximum erosion occurs where the river channel is the narrowest. This could migrate over time, depending on amount and location of net forward movement on the landslide. At present, only the middle portion on the northeast side of Locke Island is threatened by significant erosion. Little or no erosion has occurred elsewhere on the island and that is expected to continue. Sediment bars are presently forming along the southeast side of Locke Island; these bars are composed of the sediment eroded from the island and toe of the landslide upstream. Erosion of Locke Island and surficial movements of the Locke Island Landslide should continue to be monitored on a regular basis. Special consideration should be given to monitoring during high stream flow events, especially those that occur in mid-to-late June. 


\section{References}

Bjornstad BN. 2006. On the Trail of the Ice Age Floods: A Geological Field Guide to the MidColumbia Basin. Keokee Company Publishing, Inc., Sandpoint, Idaho, 302 p.

Bjornstad BN and NA Cadoret. 1997. "Geology and geomorphology in the vicinity of Locke Island, Hanford Site, Washington.” Northwest Anthropological Conference, Ellensburg, Washington, April 17-19, Abstracts with Program, pp. 26-27.

Hays WH and RL Schuster. 1987. "Maps Showing Ground Failure Hazards in the Columbia River Valley Between Richland and Priest Rapids Dam, South-Central Washington.” Miscellaneous Investigation Series, Map I-1699, U.S. Geological Survey, Reston, Virginia.

Mueller RP and DR Geist. 1999. Steelhead spawning surveys near Lock Island, Hanford Reach of the Columbia River. PNNL-13055, Pacific Northwest National Laboratory, Richland, Washington.

Nickens PR, BN Bjornstad, NA Cadoret and MK Wright. 1998. Monitoring bank erosion at the Locke Island Archaeological National Register District: Summary of 1996/1997 field activities. PNNL-11970, Pacific Northwest National Laboratory, Richland, Washington.

Schuster RL, AF Chleborad, and WH Hays. 1987. "Irrigation-induced landslides in fluvial-lacustrine sediments, south-central Washington State.” In 5th International Conference and Field Workshop on Landslides, Christchurch, New Zealand, pp. 147-156.

Triangle Associates. 2003. “White Bluffs Landslides: Assessment Report.” Prepared under contract to the U.S. Institute for Environmental Conflict Resolution and the U.S. Fish and Wildlife Service for the Hanford Reach National Monument, Seattle, Washington.

USBR. 1999. Locke Island Landslide Study, Phase I White Bluffs Area, Columbia Basin Project, Washington. U.S. Bureau of Reclamation, Pacific Northwest Regional Office, Boise, Idaho.

USCOE. 1998. Locke Island Erosion Control Feasibility Study. DOE/RL-98 0096, prepared for the U.S. Department of Energy by the U.S. Army Corps of Engineers, Walla Walla District, Walla Walla, Washington. 